\title{
MACRO- AND MICROELEMENTAL COMPOSITION OF THE ANTARCTIC FISH BLOOD SERUM
}

\author{
V. Voitsitsky¹, S. Khyzhnyak¹, O. Druzheruchenko', D. Lukashov', A. Pavlovich², O. Manilo ${ }^{3}$ \\ ${ }^{1}$ Taras Shevchenko National University of Kyiv, Kyiv \\ ${ }^{2}$ National Antarctic Scientific Center of Ukraine, Kyiv \\ ${ }^{3}$ Zoological museum of National Academy of Sciences of Ukraine, Kyiv \\ vmv@biocc.univer.kiev.ua
}

\begin{abstract}
The research materials were selected during the 9-th Ukrainian Antarctic expedition in Academic Vernadsky station region. For analysis the fish samples that related to Nototheniidae, Bathydraconidae and Chaenichthyidae were used. The elemental composition of fish blood serum was estimated by flame atomic absorption spectroscopy and X-ray fluorescence spectroscopy. The elemental analysis of blood serum of the Antarctic fish revealed the species- dependent distribution. The expedience of the fish blood serum use for environmental biotesting is proposed.
\end{abstract}

Key words: Antarctic fish, blood serum, elemental composition, biotesting.

\section{Introduction}

One of problems of the biological monitoring is the search for biochemical indicators to estimate the state of natural populations or specific variety. The data analysis of scientific literature in relation to maintenance of heavy metals in fish tissues indicates the features of accumulation and their distribution dependencing on specific belonging, physiology state and functional features of organs and tissues. Therefore, the monitoring of certain territories, including the Antarctic Region districts, must be conducted taking into account the specific differences of fish element composition which live in this district.

In the process of co-operating with an environment living organisms biogenic elements are used: hydrogen, oxygen, carbon, nitrogen, mineral and organic substances. Vital functions of cells and supporting their homoeostasis are provided by both the row of major mineral microelements ( $\mathrm{Na}, \mathrm{Ca}, \mathrm{K}, \mathrm{P}, \mathrm{N}$ etc.) which contents in an organism does not exceed $10^{-3}-10^{-12}$ mass. $\%$.

The biological significance of macroelements is many-sided: they take part in formation of mineral supporting fabrics and basic organic substances (proteins, lipids, carbonhydrates), necessary to providie of the processes of biosynthesis etc. Microelements are a large group of chemical substances which are to be divided into vitally necessary and toxic. With this it should be taken into account that certain microelements are able to show a toxic effect, depending on the concentration. Microelements influence the oxidation-restorations processes, growth and development of organism, hematosis etc. They are a biologically active substances (enzymes, vitamins, hormones, pigments). Thus the purpose of this work is the research of maintenance of major mineral microelements and microelements in the serum blood of fish of Antarctic Continent.

\section{Materials and methods}

The materials for the research were selected in the period of 09.04-05.05 during work of the 9-th Ukrainian Antarctic expedition in the district of the Academician Vernadsky station. The Academician Vernadsky station is in western part of Galindez island, one of Argentine islands archipelago. These islands is a small group islands, which are situated in seven-twelve kilometres to the west of Greham Earth and are dissociated from Antarctic to the peninsula by Penola strait.

After fish identification the blood war taken away from an anal vein. For the analysis the standards (in all 30) obtained from the different types of fishes are used. In the district of the researche individuals which belong to 3 families were found: Nototheniidae, Bathydraconidae and Chaenichthyidae. Some features of feedstock which are used for research are shown in Tab.1.

Species of Antarctic fish, their length-weight indexes and the place of catch

Table 1. (Academic Vernadsky station, 09.2004-05.2005)

\begin{tabular}{|c|l|l|c|c|c|c|}
\hline № & \multicolumn{1}{|c|}{ Species } & Place of catch & $\begin{array}{c}\text { Depth of } \\
\text { catch, } \mathrm{m}\end{array}$ & $\begin{array}{c}\text { Number of } \\
\text { samples }\end{array}$ & Weight, g & $\begin{array}{c}\text { Length, } \\
\text { sm }\end{array}$ \\
\hline 1 & $\begin{array}{l}\text { Notothenia } \\
\text { coriiceps } \\
-/ /-\end{array}$ & Meek Channel & $25-30$ & 4 & $247-411$ & $25-28$ \\
$-/ / I$ & $-/ /-$ & $30-37$ & 3 & $588-1806$ & $30-51$ \\
& $\begin{array}{l}\text { Grotto-Anvil } \\
\text { Rock- Three } \\
\text { Little Pigs }\end{array}$ & $30-35$ & 3 & $880-1068$ & $30-40$ \\
\hline 2 & Trematomus & Skua Greek & $20-30$ & 5 & $179-196$ & $20-23$ \\
\hline
\end{tabular}




\begin{tabular}{|c|l|l|c|c|c|c|}
\hline & $\begin{array}{l}\text { bernacchii } \\
-/ /-\end{array}$ & $\begin{array}{l}\text { Channel } \\
\text { Meek Channel }\end{array}$ & $15-20$ & 4 & $225-386$ & $26-28$ \\
\hline 3 & $\begin{array}{l}\text { Parachaenichthys } \\
\text { charcoti }\end{array}$ & Meek Channel & $20-25$ & 4 & $614-1049$ & $43-52$ \\
\hline 4 & $\begin{array}{l}\text { Chaenocephalus } \\
\text { aceratus }\end{array}$ & Meek Channel & $25-30$ & 7 & $769-2055$ & $48-69$ \\
\hline
\end{tabular}

The contents of major mineral microelements was determined in the serum blood. The tests were dried out in a drying closet at the temperature of $75-80^{\circ} \mathrm{C}$. Out of dried tests samples, which were added to dry ashing in a muffle stove, with temperature increase up to $450^{\circ} \mathrm{C}$ [1]. The preparation of tests to the atomic adsorption analysis was conducted by the method of acid mineralization. Tests analysis of $\mathrm{Fe}, \mathrm{Sr}, \mathrm{Ca}, \mathrm{K}, \mathrm{Cl}, \mathrm{Mg}, \mathrm{Na}, \mathrm{P}$ contents was conducted in atomic adsorption spectrophotometer.

The contents of microelements: $\mathrm{Ni}, \mathrm{Cu}, \mathrm{Zn}, \mathrm{Cr}, \mathrm{Sr}, \mathrm{Pb}, \mathrm{Cd}$ was determined in roentgen fluorescent analyzer of «XNAT-CONTROL ». The ash tests samples were located in a cuvette with bottom, covered $4 \mathrm{mkm}$ by film. The stimulation was fulfilled by $\mathrm{x}$-ray tube with titanium anode. The spectrum registration was fulfilled by the semiconducting $\mathrm{Si}(\mathrm{Li})$ detector with energy resolution of $170 \mathrm{eV}$. Oscillator and spectrometer control was fulfilled with the use of the compute by special programme. Data handling of spectrum was carried out by the method of fundamental parameters.

Experimental information was processed by generally accepted methods of variation statistics.

\section{Results and Discussion}

Of the first stage of the research the maintenance of macronutrients is conducted in the serum blood of fish. In the process of evolution the fish adjusted to the differences of gas mode of the environment existence. It is known [2, 3] that in the conditions of hypoxy the change of acid-base equilibrium is accompanied by differences of electrolytes contents in an organism. The results of the research of electrolytes contents of serum blood in different types of fish of Antarctic Continent are presented in Tab. 2. The contents of the investigated elements in N.coriiceps in characteristic to saltwater fish [4]. At the same time, the representatives of other kinds (T.bernacchii and of C.aceratus) are characterized by the decreased contents of $\mathrm{Na}^{+}, \mathrm{K}^{+}, \mathrm{Cl}^{+}$in a serum and also somewhat inreased contents of $\mathrm{Na}^{2+}$. It is admitted [4], that ionic exchange at fish in water with low $\mathrm{pH}$ is connected with the surplus output of sodium outside at the simultaneous inconing of $\mathrm{H}^{+}$inside of the organism. The increased level of $\mathrm{Ca}^{2+}$ in the serum blood of $\mathrm{T}$. bernacchii and C. aceratus can testify to presence of mechanisms able to counteract the oxygen deficit, as for the fish of these kinds the of $\mathrm{Ca}^{2+}$ contents in a liver is also increased. It testifies the possibility of complex $\mathrm{Ca}_{3}\left(\mathrm{PO}_{4}\right)_{2}$ formation, that results in growth of cation transport in a cell. It is considered [5], $\mathrm{Ca}^{2+}$ to take part activating a phosphorylase A, take part in the mechanism of oxydated phosphorylating depressin of in mitochondrions at anoxya. The formation of similar complexes is observed at stressed situations [6]. Similar differences for the different types of fish can be display of mechanisms which are about to support an acid-based equilibrium and ionic exchange, at hypoxic terms of mionectic temperature of water environment.

Electrolytic composition of the Antarctic fish blood serum, $\mathrm{mMol} / \mathrm{L}(\mathrm{M} \pm \mathrm{m}, \mathbf{n}=7)$

\begin{tabular}{|l|c|c|c|c|c|c|}
\hline \multicolumn{1}{|c|}{ Species } & $\mathrm{Na}$ & $\mathrm{K}$ & $\mathrm{Ca}$ & $\mathrm{Mg}$ & $\mathrm{P}$ & $\mathrm{Cl}$ \\
\hline Notothenia coriiceps & $223,5 \pm 21$ & $6,01 \pm 0,91$ & $4,84 \pm 0,91$ & $2,32 \pm 0,81$ & $3,91 \pm 0,9$ & $181,8 \pm 19$ \\
\hline Trematomus bernacchii & $187,0 \pm 18$ & $5,26 \pm 0,98$ & $6,31 \pm 1,01$ & $4,97 \pm 0,98$ & $3,13 \pm 0,81$ & $164,5 \pm 16$ \\
\hline Chaenocephalus aceratus & $60,5 \pm 17$ & $4,05 \pm 1,1$ & $8,10 \pm 1,21$ & $2,20 \pm 0,81$ & $3,9 \pm 1,0$ & $134,5 \pm 13$ \\
\hline
\end{tabular}

Table 2.

The specific variety of Antarctic fish, depending on the terms of existence, are characterized by the features of physiology, foresees differences in flowing of biochemical processes. The obtained results testify the specific differences of functioning of the systems that take part in support of acid-base balance of organism.

At the next stage of the research of microelements contents is determined in by the serum blood. The results of the research are resulted in Tabl. 3 and Fig. So according to the results the rows of elements investigated are built in the serum blood for the different types of fish:

N.coriiceps $-\mathrm{Fe}>\mathrm{Zn}>\mathrm{Cu}>\mathrm{Sr}>\mathrm{Cr}>\mathrm{Ni}>\mathrm{Mn}, \mathrm{Pb}>\mathrm{Cd}$

T.bernacchii $-\mathrm{Fe}>\mathrm{Zn}>\mathrm{Cu}>\mathrm{Sr}>\mathrm{Cr}, \mathrm{Ni}>\mathrm{Pb}>\mathrm{Mn}>\mathrm{Cd}$

C. aceratus $-\mathrm{Zn}>\mathrm{Cu}>\mathrm{Fe}, \mathrm{Cr}>\mathrm{Ni}>\mathrm{Sr}>\mathrm{Mn}>\mathrm{Pb}>\mathrm{Cd}$

The rows obtained do not correspond to a row at of chemical composition determination of freshwater fish, that containg [7]: $\mathrm{Fe}>\mathrm{Zn}>\mathrm{Cu}, \mathrm{Mn}, \mathrm{Ni}>\mathrm{Pb}>\mathrm{Cr}>\mathrm{Co}, \mathrm{Cd}, \mathrm{Hg}$.

Microelemental composition of the Antarctic fish blood serum, $\mu \mathrm{Mol} / \mathrm{L}(\mathrm{M} \pm \mathbf{m}, \mathbf{n}=8)$

\begin{tabular}{|l|c|c|c|c|c|c|c|c|}
\hline \multicolumn{1}{|c|}{ Species } & $\mathrm{Ni}$ & $\mathrm{Cu}$ & $\mathrm{Zn}$ & $\mathrm{Fe}$ & $\mathrm{Cr}$ & $\mathrm{Sr}$ & $\mathrm{Pb}$ & $\mathrm{Cd}$ \\
\hline Notothenia & 3,38 & 28,5 & 163,0 & 260,0 & 7,3 & 9,57 & 1,25 & 0,54 \\
coriiceps & $\pm 1,01$ & $\pm 3,1$ & $\pm 12,1$ & $\pm 21,3$ & $\pm 1,0$ & $\pm 0,10$ & $\pm 0,02$ & $\pm 0,02$ \\
\hline Trematomus & $3,89 \pm$ & $15,6 \pm$ & $139,5 \pm$ & $185,7 \pm$ & $4,8 \pm$ & $5,15 \pm$ & $1,41 \pm$ & \\
bernacchii & 0,91 & 2,1 & 23,1 & 15,2 & 0,9 & 0,15 & 0,03 & Traces \\
\hline
\end{tabular}

Table 3. 


\begin{tabular}{|l|c|c|c|c|c|c|c|c|}
\hline $\begin{array}{l}\text { Parachaenichthys } \\
\text { charcoti }\end{array}$ & $\mathrm{n} / \mathrm{d}$ & $\begin{array}{c}31,2 \pm \\
1,8\end{array}$ & $\begin{array}{c}183,8 \pm \\
18,1\end{array}$ & $\mathrm{n} / \mathrm{d}$ & $\begin{array}{c}4,0 \pm \\
0,8\end{array}$ & $\mathrm{n} / \mathrm{d}$ & Traces & $\begin{array}{c}0,80 \pm \\
0,02\end{array}$ \\
\hline $\begin{array}{l}\text { Chaenocephalus } \\
\text { aceratus }\end{array}$ & $4,0 \pm$ & $30,7 \pm$ & $174,2 \pm$ & $11,1 \pm$ & $9,5 \pm$ & $3,41 \pm$ & $0,56 \pm$ & $0,24 \pm$ \\
1,2 & 3,1 & 15,1 & 5,1 & 1,5 & 0,14 & 0,03 & 0,01 \\
\hline
\end{tabular}

In general the investigated fish have the highest level of $\mathrm{Fe}, \mathrm{Zn}, \mathrm{Cu}$, that is in accordance scientific literature [8,9] about the high concentration of these elements in fish blood. However, C.aceratus is characterized by deteased contents of $\mathrm{Fe}$, that is connected with the physiology features characteristics.

The zinc contents in freshwater and saltwater fish is below, in comparison with the water-plants or invertebrates. Thus the accumulation of zinc in the organism of isn't connected with the sish food. It is known that the owerage contents of zinc in a liver for 8 types of saltwater fish from
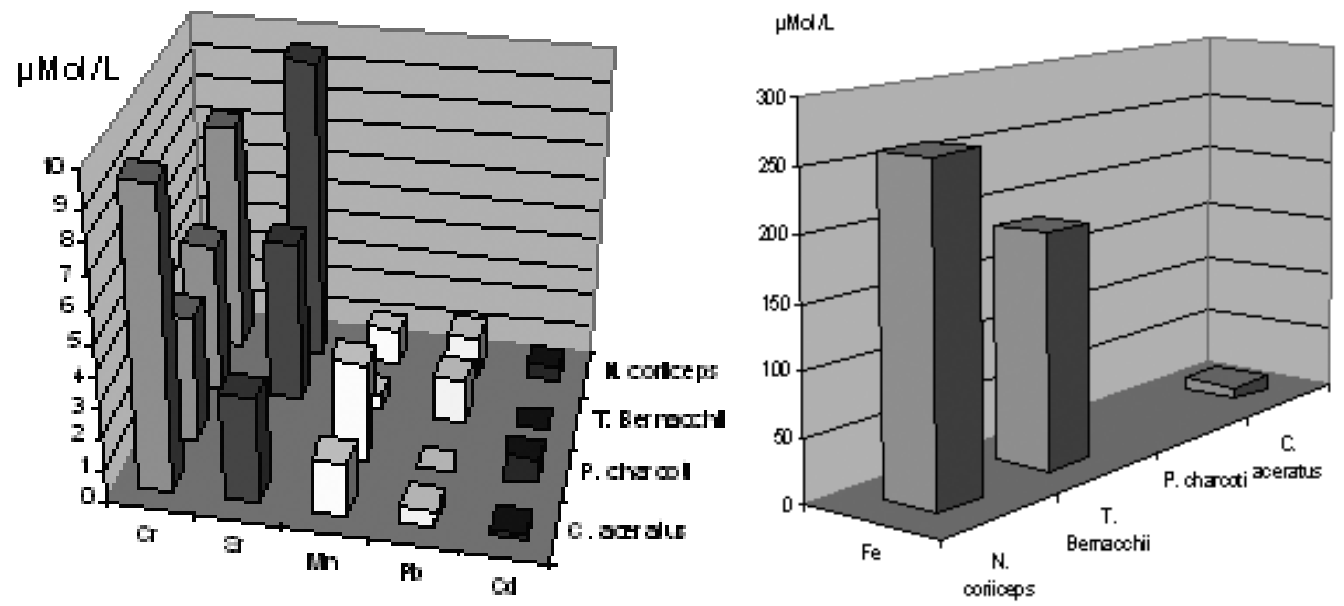

Fig. Microelemental composition of the antarctic fish blood serum, $\mu \mathrm{Mol} / \mathrm{L}$.

New Zealand makes $76 \mathrm{mg} / \mathrm{kg}$ [10]. According to sanitary requirements the concentration of zinc not must exceed 40 $\mathrm{mg} / \mathrm{kg}$ of raw weight in saltwater fish. The conducted research show to increased contents of zinc in blood of fish of the Antarctic Region in comparison with.

The contents of copper in saltwater fishes is increased in comparison with the freshwater finfishess. In marine water the contents of copper intissnes reaches $2 \mathrm{mg} / \mathrm{kg}$, and strong contamination of the environment can result in 3-6 $\mathrm{mg} / \mathrm{kg}$. It is determined that the contents of copper is within the limits of saltwater fish characteristic. Thus, only in blood of T.bernacchii its concentration 2 times lower in comparison with other kinds.

The contents of chrome, characterized by mutagenes properties, is low in saltwater and freshwater fish. For example, the contents of chrome in Mediterranean (Lebanon) achieves $1,6 \mathrm{mg} / \mathrm{kg}$ of raw weight, in other districts and types of fish its contents laer [10]. A certain contents of chrome is discovered in the fish investigated, that is the lowest for T.bernacchii but P.charcoti. The contents of manganese in saltwater fish is lower, in comparison with freshwater. In the Antarctic fish it isn't, in the serum blood of T.bernacchii it is the lowest.

Lead and cadmium are toxic elements which mainly are accumulated in a liver. However there is the report, that cadmium influences on functioning of some enzymes, and is possibly, necessary for a carbohydrate exchange [11]. The results of research testify their insignificant concentration in blood of the researched fish. Nickel insignificantly differs its toxicness, however the growth of its contents in the organism of fish can be harmful. In blood of the Antarctic fish the concentration of nickel does not differ for all types of fish.

Thus, T.bernacchii is characterized by the least contents of heavy metals. C.aceratus characterized by the lowest contents of iron and stroncium, and has the greatest chrome. The analysis of elements contents in the whey of fish blood of Antarctic Continent allowed to find out the features of their distribution depending on specific belonging and appopriatness of the use of whey of blood for the biotesting of environment.

\section{Conclusions}

The obtained results of the electrolyte content estimation in blood serum of the Antarctic fish indicate the species differences in the functioning of the systems that maintain the acid-base balance in the organism.

The species-dependent differences in macroelemental content in blood serum of the Antarctic fish are revealed.

The highest content of the heavy metals in blood serum is characteristic for Notothenia coriiceps.

The obtained results indicate that it is necessary to take into account the species nature in monitoring of the environmental pollution of the heavy metals by estimation of their content in different fish organs.

\section{Acknowledgments}

This work was supported by a grant from the National Antarctic Scientific Center of Ministry of Education and Science of Ukraine.

\section{References}


1. Karykin A.V., Gribovskay I.F. Emissive spectral analysis of biosphere objects. M.: Chemistry,1979. 207 p.

2. Kotsar N.I. Действие колебаний температуры и газового режима водной среды на енергообмен у сеголетков карпа // Fish-compani. - 1980. - V. 40. - P. 5-8.

3. Thomas S., Fievet B., Motais R., Effect of deep hypoxia on acid base balance in trout: role of ion transfer proceses // Amer J. Physiol. - 1986. - 250, N 3. - P. 319 - 327.

4. Solomatina V.D. Электролитный состав тканей карпа, акклимируемого к снижению уровня кислорода в водной среде // Gidrobiol.-Zyrnal. - 1990. V. 26, № 5. - P. 37-41.

5. Bragin E.O., Sorokov V.I., Kogan E.M., Vladimirov Yu.N. Роль ионов кальция в аноксическом повреждении окислительного фосфорилироавния в митохондриях // Voprosi Med. Chemistry. - 1975. - 21, № 2. - P. $150-154$.

6. Derkachev E.F. Bioenergetika and stress // Регуляция енергетического обмена и устойчивость организма. Puschino, 1975. - P. 139-143.

7. Patin S.A., Morosov N.P. Микроэлементы в морских организмах и экосистемах. M.: Legkay and pischevay Prom.1981. 185 p.

8. Brooks R.R., Rumsey D. Heavy metals in some New Zealand commerciel sea fishes // N.Z.Y.: Mar and Freshwater Res. - 1974. - 8, N 1. - P. 155-166.

9. Neda T., Suquabi Y., Xahahara M. et al. Concentration factors of some elements for mesopelagie fishes // J. Radiat. Res. - 1980. - 21, N 1. - P. 12-13.

10. Mur Dz.V., Ramamurti C. The heavy metal in natural water. M.: Mir, 1987. 285 p.

11. Chus M. The inorganic chemistry of biological prosses. M.: Mir. 1983. 414 p. 